\title{
ESSENTIAL OILS IN THE MANAGEMENT OF SOFT ROT OF KALE IN THE BRAZILIAN SEMIARID REGION
}

\author{
ÓLEOS ESSENCIAIS NO MANEJO DA PODRIDÃO MOLE EM COUVE NO \\ SEMIÁRIDO BRASILEIRO
}

\author{
Marcia Ferreira QUEIROZ ${ }^{1}$; Meridiana Araujo Gonçalves LIMA²; \\ Josineide Edinalva PEREIRA ${ }^{1}$; Karol Alves BARROSO ${ }^{1}$; Cristiane Domingos DA PAZ $^{2}$; \\ Angélica Maria LUCCHESE ${ }^{3}$;Ana Rosa PEIXOTO ${ }^{2}$ \\ 1. Posgraduate Program in Agronomy: Irrigated Horticultute, State University of Bahia, Juazeiro, BA, Brazil \\ marciaqueiroz.mfq@gmail.com; 2. Department of Technology and Social Sciences, State University of Bahia, Juazeiro, BA, Brazil; \\ 3. Departament of Exact Sciences, State University of Feira de Santana, Feira de Santana, BA, Brazil.
}

\begin{abstract}
The aim of this study was to analyze the effect of essential oils on the control of soft rot of kale. Clove essential oil at $0.25 \%$, lemongrass and palmarosa essential oils at $0.5 \%$, melaleuca and orange essential oils at $0.75 \%$, bergamot, rosemary, sage and ginger essential oils at $1 \%$ were evaluated for the in vitro inhibition of Pectobacterium carotovorum subsp. brasiliensis (Pcb) and control of soft rot of kale, sprayed 72 hours before or seven hours after inoculation. Clove, citronella, bergamot, rosemary, palmarosa, sage, melaleuca, and lemongrass oils completely inhibited the growth of Pcb. Lemongrass oil $(0.5 \%)$ caused $0 \%$ of disease incidence (INC), providing $100 \%$ of disease control in both periods of inoculation. Clove oil $(0.25 \%)$ showed a lower INC (25\%) when applied after inoculation, providing a control percentage of $71.42 \%$. The lemongrass and clove essential oils were analyzed by GC/FID (Gas Chromatography - Flame Ionization Detector) and by GC/MS (Gas Chromatography /Mass Spectrometer). The major components were eugenol $(91,9 \%)$ for clove oil and citral, isometric mixture of neral $(34,1 \%)$ and geranial $(42,9 \%)$ for lemongrass oil. The Minimum inhibitory concentration (MIC) of lemongrass, clove oils and their major components (citral and eugenol, respectively) was determined by using a broth macrodilution technique, as well as they were evaluated at different concentrations on the control of soft rot of kale, sprayed according descriptions above. The MIC was $0.03125 \%$ for citral, and 0.0625 and $0.125 \%$ for lemongrass and clove oils, respectively. Eugenol didn't show MIC. Lemongrass oil at $0.125 \%$ (post-inoculation) and citral at $0.125 \%$ (pre and post-inoculation) provided the highest percentages of disease control (33.33, 50, and $100 \%$, respectively). Clove oil at $0.125 \%$ (post-inoculation) showed better effectiveness than eugenol $(0.25 \%)$, providing a percentage of disease control of $16.67 \%$. Lemongrass and clove essential oils were the most effective in control of soft rot of kale, suggesting that these oils have a potential to be used as antibacterial agents.
\end{abstract}

KEYWORDS: Alternative control. Brassica oleraceae var. acephala. Citral. Clove. Eugenol. Lemongrass. P. carotovorum subsp. brasiliensis.

\section{INTRODUCTION}

Kale (Brassica oleracea L. var. acephala DC) is cultivated throughout the year in Brazil, and it remains productive for several months, which makes it an attractive source of income, mostly for family farmers who cultivate it in small areas during the year (SILVA et al., 2012b). One of the factors that might compromise crop yield is phytobacterioses, e.g. soft rot caused by pectinolytic bacteria of the genus Pectobacterium (FILGUEIRA, 2008; MARINGONI; SILVA JR, 2016).

The species $P$. carotovorum is considered one of the top ten phytopathogenic bacteria in scientific and economic importance worldwide (MANSFIELD et al., 2012). Soft rot of kale is commonly caused by $P$. carotovorum (MARINGONI; SILVA JR, 2016). However, the genus Pectobacterium is comprised of a diversity of species and subspecies (DUARTE et al., 2004; GARDAN et al., 2003; HAUBEN et al., 1998; NABHAN et al., 2013; SAMSON et al., 2005), most of which have no specificity and might infect a wide range of hosts, and one crop might be infected by several species or subspecies of this genus (MARIANO et al., 2005). In 2004, a new, highly aggressive subspecies, designated as $P$. carotovorum subsp. brasiliensis Duarte et al. (2004) (Pcb), was characterized in potato crops in Brazil (DUARTE et al. 2004). Since then, this subspecies has been reported in several countries and botanic families, including Brassicaceae, e.g. chinese 
Essential oils...

cabbage (Brassica pikinensis L) (LEE et al. 2014). In Brazil, the first report of Pcb causing severe soft rot symptoms in kale was published in 2017 (QUEIROZ et al., 2017).

Soft rot disease is difficult to control due to the heterogeneity of species of the genus Pectobacterium, which have a wide host range and geographical distribution (LEE et al. 2014), are capable of surviving in crop remains, in the soil, and in the rhizosphere of cultivated or invasive plants (CHARKOWSKI, 2015; MARINGONI; SILVA JR, 2016), and is transmitted through different means (HADAS et al. 2001; MARINGONI; SILVA JR, 2016). Nevertheless, there are some integrated control measures involving: planting on welldrained soils, insect control, elimination of diseased plants, crop rotation (MARIANO et al., 2001; MARINGONI; SILVA JR, 2016), biological control (SILVA et al., 2014b), use of resistance inducers (acibenzolar-S-methyl) (BENELLI; DENARDIN; FORCELINI, 2004), use of calcium phosphite, potassium phosphite (SILVA et al., 2014b), plant extracts (SILVA et al., 2012a), and chemical control using antibiotics and copper-based fungicides (CHARKOWSKI, 2015; INOUE-NAGATA et al., 2016). However, there is no registered product in Brazil for the control of soft rot in brassicas (AGROFIT, 2018).

In the last years plant essential oils have been extensively studied and are a promising alternative for plant disease management due to their antimicrobial properties (DEBERDT et al., 2018; SILVA et al., 2017). Several previous studies have shown that essential oils can be used in the management of soft rot caused by Pectobacterium species, such as $P$. carotovorum subsp. carotovorum (Jones) Haubenet al (Pcc) in chinese cabbage (GUERRA et al., 2014) and lettuce (Lactuca sativa L.) (SILVA et al., 2012a). Positive in vitro results of essential oils were also obtained for Pcc (COSTA et al. 2008a; 2008b; FERNÁNDEZ et al. 2014; JEONG et al. 2009; SOTELO-BOYÁS et al., 2015). In a study by Joshi et al. (2016), they demonstrate the potential envolviment of essential oils active compound in the control of $\mathrm{Pcb}$ and $P$. aroidearum Nabhan et al. (2013) on potato tubers, cabbage and calla lily leaves as hosts.

However, no studies have been found involving the use of essential oils in the management of soft rot caused by Pcb on kale.

Therefore, the aim of present study was to evaluate the in vitro and in vivo inhibitory effects of different concentrations of essential oils on the growth of Pcb and on the control of soft rot of kale.
QUEIROZ, M. F. et al.

\section{MATERIAL AND METHODS}

Experiments were conducted at the Phytopathology Laboratory and Greenhouse of the Department of Technology and Social Sciences of the Universidade do Estado da Bahia (UNEB), Campus III, Juazeiro, Bahia State, Brazil and Universidade Estadual de Feira de Santana (UEFS), Feira de Santana, Bahia State, Brazil.

\section{Obtaining and preparation of the inoculum}

Isolate of $P$. carotovorum subsp. brasiliensis (UNEB8) was obtained from the collection of cultures of the Laboratory of Phytopathology of UNEB, having been obtained from kale plants (cv. Manteiga) with severe soft rot symptoms and identified through biochemical, metabolic and molecular tests (QUEIROZ et al., 2017). For its use in the experiments, UNEB8 isolate was cultivated on peptone-casamino acidglucose medium (CPG) for $48 \mathrm{~h}$ for the preparation of the suspensions. Bacterial suspension concentration was adjusted using a photocolorimeter (Analyser 500, Brazil) to $1 \times 10^{9} \mathrm{CFU} \mathrm{mL}^{-1}$.

\section{Essential Oils (EOs) and test for phytotoxicity}

The EOs used were of clove (Eugenia caryophyllata Thunb), citronella (Cymbopogon winterianus Jowitt), bergamot (Citrus bergamia Risso et Poiteau), rosemary (Rosmarinus officinalis L.), palmarosa (Cymbopogon martin [Roxb.] Wats), sage (Salvia sclarea L.), ginger (Zingiber officinalis Roscoe), melaleuca (Melaleuca alternifolia Maiden $\&$ Betche, Cheel), orange (Citrus aurantium L.), and lemongrass (Cymbopogon citratus Stapf), all 100\% pure and produced by Phytoterapica (Phytoterapica - Solua Comercial Ltda., São Paulo, Brazil). Citral and eugenol compounds were purchased from Sigma-Aldrich, Brazil.

In all the experiments, 60-day-old kale plants (cv. Manteiga) were used. Sowing was performed on polyurethane trays containing commercial substrate. After 18 days, seedlings were transplanted to vases with capacity of $1000 \mathrm{~mL}$ containing a 2:1 (v/v) mixture of clayish soil and sand, previously sterilized in autoclave. Irrigation was performed as required.

To determine potential phytotoxicity and choose the concentrations to be used, the 10 EOs were previously tested at concentrations of $0 ; 0.25$; $0.50 ; 0.75$ and $1.00 \%$, obtained by dilution in sterilized distilled water (SDW) mixed with Tween 20 (1:1). Kale plants were sprayed until leaf surface was completely wet. Phytotoxicity evaluation was performed by observing abnormal plant 
Essential oils...

development or color up to 48 hours after treatment application (GUERRA et al., 2014). Experiments were carried out in a completely randomized factorial block design $10 \times 5$, comprised of $10 \mathrm{OEs}$ and five concentrations. Each treatment had five replicates, and each replicate was represented by a plant.

\section{In vitro sensitivity of Pectobacterium carotovorum subsp. brasiliensis to essential oils}

In vitro sensitivity of $\mathrm{Pcb}$ to different EOs was determined by colony counts per dish (PARET et al., 2010). One hundred milliliters of CPG medium were used in each treatment. The medium was amended with $250 \mu \mathrm{L}, 500 \mu \mathrm{L}, 750 \mu \mathrm{L}$, and $1000 \mu \mathrm{L}$ of oils to give final concentrations of 0.25 ; $0.50 ; 0.75$ and $1.00 \%(\mathrm{v} / \mathrm{v})$, respectively. Clove oil was used at $0.25 \%$, lemongrass and palmarosa oils were used at $0.50 \%$, citronella, orange, and melaleuca were used at $0.75 \%$, and the others were used at $1.00 \%$. The medium mixed with emulsified oils in Tween $20(1: 1)$, at their corresponding concentrations, was poured into Petri dishes and cooled in a laminar flow chamber for $20 \mathrm{~min}$. After that, $100 \mu \mathrm{L}$ of bacterial suspension $\left(10^{3} \mathrm{CFU} \mathrm{mL} \mathrm{mL}^{-1}\right)$ was spread over the medium. The Petri dishes were maintained at $28{ }^{\circ} \mathrm{C}$ for $48 \mathrm{~h}$. Subsequently, the number of colonies per dish was counted and CFU $\mathrm{mL}^{-1}$ was calculated. The medium with addition of 1 $\mathrm{mL}$ of Tween 20 represented the control treatment. Experiment was comprised of 11 treatments (10 essential oils + control) with four replicates and three plots, and each plot was represented by a Petri dish.

\section{Essential oils in the control of soft rot in kale}

EOs were sprayed onto kale plants as previously described, in different periods: prior to inoculation-pre (oils applied 72 hours prior to inoculation), or after inoculation-post (oils applied seven hours after inoculation). Plants were inoculated at the base of the petiole, using the pricking method adapted from Ren, Petzoldt and Dickson (2001), in which the plant tissue is penetrated with the insertion of an entomological pin, followed by the deposition of $10 \mu \mathrm{L}$ of bacterial suspension. After that, plants were placed in a moist chamber for six hours, and remained under greenhouse conditions ( $\mathrm{T}$ of $29.5^{\circ} \mathrm{C} \pm 2$ ). Incidence (INC), expressed by the percentage of diseased plants, was evaluated $48 \mathrm{~h}$ after inoculation (in the experiment in which oils were applied prior to inoculation) or $48 \mathrm{~h}$ after the application of essential oils (in the experiment in which oils were applied after inoculation).
QUEIROZ, M. F. et al.

The experimental design was completely randomized, and each experiment was comprised of 11 treatments, with 10 essential oils and 1 control (treated with SDW, inoculated with Pcb). Each treatment had four replicates, and each replicate was comprised of one plant, with three leaves inoculated.

The essential oils of lemongrass and clove for promoting the highest percentages of soft rot control were selected to conduct further experiments.

\section{Chemical composition of lemongrass and clove essential oils}

Essential oils were analyzed by GC/FID (Gas Chromatography - Flame Ionization Detector) and by GC/MS (Gas Chromatography /Mass Spectrometer) as Silva, Uetanabaro and Lucchese (2013) with some modifications. Before injection, $25 \mathrm{mg}$ of essential oil were diluted in $1 \mathrm{~mL}$ of dichloromethane, and $0.5 \mu \mathrm{L}$ was injected. The GC used was a Varian ${ }^{\circledR}$ CP-3380 model, equipped with a FID detector. The analysis was performed with a Chrompack CP-SIL $5(30 \mathrm{~m} \times 0.5 \mathrm{~mm}$ i.d. x 0.25 $\mu \mathrm{m}$ film) capillary column. The temperatures of the FID and of the injector were $240{ }^{\circ} \mathrm{C}$ and $220{ }^{\circ} \mathrm{C}$, respectively. The oven temperature was programmed at $60{ }^{\circ} \mathrm{C}$ with an increase of $3{ }^{\circ} \mathrm{C} / \mathrm{min}$ until $240{ }^{\circ} \mathrm{C}$, and maintained for $20 \mathrm{~min}$. The carrier gas was helium, at a flow rate of $1 \mathrm{~mL} / \mathrm{min}$, in split mode (ratio of 1:50). The results are expressed in relative percentage of each constituent, calculated by normalisation of the chromatographic peak areas reported as mean value of three oils injections. The GC-MS used was a Shimadzu GC-2010 model, coupled to a GC/MS-QP 2010 Shimadzu mass detector model with a DB-5 ms $(30 \mathrm{~m} \times 0.25 \mathrm{~mm}$ i.d. $\times 0.25 \mu \mathrm{m}$ film) capillary column, under the same analysis conditions as set out above. The temperature of the ionization source was maintained at $240^{\circ} \mathrm{C}$, the ionization energy at $70 \mathrm{eV}$ and the current at $0.7 \mathrm{kV}$. Retention indices of the separated compounds were determined on the basis of a homologous series of $n$-alkanes (C8- C24). The identification of the constituents was performed by comparison of the retention indices (Kovats indices) with literature data (ADAMS, 2017) and authentic reference compounds, as well as by MS matching with National Institute of Standards and Technology libraries (NIST21 and NIST107). 


\section{Determining minimum inhibitory concentration (MIC) of lemongrass and clove essential oils and their major components}

Lemongrass and clove EOs with their major components, citral and eugenol, respectively, were initially emulsified in $0.05 \mathrm{~mL}$ of Tween 20 and diluted in SDW to obtain the standard solution of initial concentration of $1 \%$ for lemongrass and citral, and $0.5 \%$ for clove and eugenol. MIC was determined by using a broth macrodilution technique (CLINICAL LABORATORY STANDARDS INSTITUTE, 2015) with modifications. Sterilized test tubes were used to perform serial dilutions, to which $400 \mu \mathrm{L}$ of the CPG medium without agar were added, followed by $600 \mu \mathrm{L}$ of the Pcb bacterial suspension $\left(10^{3} \mathrm{CFU}\right.$ $\left.\mathrm{mL}^{-1}\right)$. After that, $1 \mathrm{~mL}$ of the standard essential oil or major component solution was added to obtain the initial concentration of $0.5 \%$ for lemongrass oil and citral, and $0.25 \%$ for clove oil and eugenol. Subsequent concentrations were obtained by serial dilution, transferring $1 \mathrm{~mL}$ of the content into the subsequent tube. For lemongrass oil and citral, the concentrations obtained were: $0.5,0.25,0.125$, 0.0625 , and $0.03125 \%$. For clove oil and eugenol, the concentrations obtained were: $0.25,0.125$, $0.0625,0.03125$, and $0.015625 \%$. To follow the growth of Pcb, essential oils and major components were not added. For sterilization control, on the other hand, only the culture medium was added to the tubes, which were incubated at $28{ }^{\circ} \mathrm{C}$ for $48 \mathrm{~h}$. MIC corresponded to the last dilution in which the presence of bacterial precipitate was not observed.

Experiment design was completely randomized, with 22 treatments represented by lemongrass and clove essential oils, and their major components, citral and eugenol, at five concentrations, plus Pcb medium and growth control, with four replicates, each one represented by a test tube.

To confirm the bactericide activity of EOs and major components, $100 \mu \mathrm{L}$ aliquots of dilutions corresponding to MIC were sowed on the CPG medium. Subsequently, Petri dishes were incubated at $28{ }^{\circ} \mathrm{C}$ for $48 \mathrm{~h}$. Results were descriptively analyzed according to the presence or absence of bacterial growth.

\section{Effect of MIC of lemongrass and clove essential oils and their major components on the control of soft rot of kale}

Lemongrass and clove essential oils, with their major components, citral and eugenol, respectively, were sprayed prior to or after pathogen inoculation in kale plants according to the methodology previously described. Inoculation and INC evaluations were carried out according the descriptions above.

Experiment design was completely randomized with eight treatments each, comprised of clove oil $(0.125 \%)$; lemongrass oil $(0.0625 \%$ and $0.125 \%)$; eugenol $(0.25 \%)$; citral $(0.03125 \%$, $0.0625 \%$, and $0.125 \%$ ), and control (treated with ADE, inoculated with Pcb). Each treatment had four replicates, and each replicate was comprised of one plant, with three leaves inoculated.

\section{Statistical analyses}

All experiments and tests shown were repeated twice. Statistical analyses were performed with the help of STATISTIX ${ }^{\circledR}$ (version 9.0, Analytical Software, Tallahassee) and Assistat (version 7.6) programs. The significance level of $5 \%$ was adopted in all statistical procedures.

\section{RESULTS AND DISCUSSION}

In the assay performed in a greenhouse to determine phytotoxic concentrations of EOs, rosemary, sage, bergamot, and ginger oils did not cause phytotoxicity at any of the concentrations tested. On the other hand, citronella, melaleuca, and orange oils at $1 \%$ were phytotoxic, as were lemongrass and palmarosa, at concentrations of 0.75 and $1 \%$, and clove oil, at $0.5,0.75$, and $1 \%$. The symptoms of phytotoxicity are characterized by the presence of leaf spots, and clove oil at concentrations higher than $0.25 \%$ caused dry leaves and plant death.

EOs employed in phytopathogen control are generally used at concentrations ranging from 0.1 to 1\% (ALVES et al. 2014; GUERRA et al. 2014; HUANG; LAKSHMAN, 2010; SILVA et al., 2012a). The higher these concentrations, the more phytotoxicity they might cause, which precludes their use in the alternative control of plant diseases. Thus, we used the highest non-phytotoxic concentration of each essential oil in subsequent experiments.

Regarding the in vitro sensitivity of Pcb to EOs, rosemary, bergamot, sage oils at $1 \%$, citronella, melaleuca oils at $0.75 \%$, lemongrass, palmarosa at $0.5 \%$, and clove oil at $0.25 \%$ completely inhibited pathogen growth $(P \leq 0.05)$ after $48 \mathrm{~h}$ of incubation at $28{ }^{\circ} \mathrm{C}$. On the other hand, essential oils of ginger at $1 \%$ and orange at $0.75 \%$ did not significantly inhibit bacterial growth compared to the control treatment (Table 1). 
Table 1. In vitro sensitivity of Pectobacterium carotovorum subsp. brasiliensis to essential oils, determined by colony counts per Petri dish.

\begin{tabular}{lll}
\hline Treatments & Concentrations $(\%)$ & $\log (\mathrm{UFC} / \mathrm{mL}+1)$ \\
\hline Rosemary & 1.00 & $0 \mathrm{a}^{1}$ \\
Bergamot & 1.00 & $0 \mathrm{a}$ \\
Lemongrass & 0.50 & $0 \mathrm{a}$ \\
Citronella & 0.75 & $0 \mathrm{a}$ \\
Clove & 0.25 & $0 \mathrm{a}$ \\
Melaleuca & 0.75 & $0 \mathrm{a}$ \\
Palmarosa & 0.50 & $0 \mathrm{a}$ \\
Sage & 1.00 & $0 \mathrm{a}$ \\
Ginger & 1.00 & $8.53 \mathrm{~b}$ \\
Orange & 0.75 & $8.47 \mathrm{~b}$ \\
Control & - & $8.62 \mathrm{~b}$ \\
\hline${ }^{1}$ Means followed by the same letter on the column do not differ from each other according to Tukey's test $(P \leq 0.05)$.
\end{tabular}

In vitro microbial activity of EOs has been proved by several authors, including for phytopathogenic bacteria. Paret et al. (2010) observed that palmarosa and lemongrass oils at 0.07 and $0.14 \%$ completely inhibited the growth of Ralstonia solanacearum (Smith) Yabuuchi et al. (Rs). Amorim et al. (2011), testing the effect of different concentrations $(1.25,3.5,3.75$, and $5 \%)$ of EOs on the growth of Rs, observed that citronella and clove oils inhibited bacterial growth at all concentrations tested. Lucas et al. (2012a) observed the direct toxic effect of citronella, clove, lemongrass, eucalyptus, melaleuca, thyme (Thymus vulgaris L.), and cinnamon (Cinnamomum zeylanicum Blume) oils at $10 \%$ on Xanthomonas vesicatoria (ex Doidge) Vauterin et al. On the other hand, Silva, Martins and Alves (2014a) observed that citronella, lemongrass, cinnamon, and eucalyptus (Corymbia citriodora Hill \& Johnson) oils at $1 \%$, and thyme and clove oils at $10 \%$ effectively inhibited the growth of Pseudomonas syringae pv. tomato (Okabe) Young, Dye \& Wilkie. These results reinforce the antibacterial potential of palmarosa, lemongrass, citronella, clove, and melaleuca essential oils, which was also observed in our study.

Our results on potential of EOs were further corroborated with other studies, which confirmed the antibacterial potential of EOs on Pcc. Citronella essential oil at $1.00 \%$ and rosemary essential oil at $4.00 \%$ showed high inhibition on six Pcb isolates obtained from Brassica oleraceae L. var. capitata DC and Lactuca sativa L. (COSTA et al. 2008a; 2008b). Moreover, Jeong et al. (2009) proved the inhibitory activity of lemongrass oil on three Pcc isolates, with complete inhibition at $0.5 \%$. This result agree with results of our investigation, in which lemongrass oil at $0.5 \%$ completely inhibited the growth of Pcb.

Other essential oils have shown effectiveness on Pcc. Fernández et al. (2014) observed that thyme essential oil at $0.10 \%$ completely inhibited the growth of Pcc, whereas Sotelo-Boyás et al. (2015) observed inhibitory activity of thyme oil at $2.80 \%$ and lime (Citrus aurantifolia (Cristm.) Swingle) oil at $11.20 \%$ on this pathogen.

The bactericide activity of rosemary, citronella, melaleuca, palmarosa, clove, and lemongrass EOs observed in this study might be related to their complex chemical constituents, such as terpens and aromatic compounds (BAKKALI et al. 2008).

Components of essential oils are highly cytotoxic and their antimicrobial activity occurs due to interference in cell wall structure and cytoplasm membranes, increasing permeability and loss of cell constituents, changing a variety of enzyme systems, including those involved in the production of cell energy, synthesis of structure components, and inactivation or destruction of genetic material (BURT, 2004; BAKKALI et al. 2008). Huang and Lakshman (2010) suggested that the components of clove oil were mostly responsible for its antibacterial properties on Pcc, Rs, Rhizobium rhizobacter (Beijerinck and van Delden) Young et al., Xanthomonas hortorum pv. Pelargonii (Brown) Vauterin et al., Streptomyces spp., and Rhodococcus fascians (Tilford) Good fellow.

In this study, essential oils of ginger and orange did not show satisfactory results. However, some studies have already observed the bioactivity of ginger oil on Rs (AMORIM et al. 2011), Staphylococcus aureus, and Escherichia coli (SILVA et al., 2009). Some Pcb bacterial cells have 
Essential oils...

probably remained viable and were capable of multiplying, even in the presence of these oils. Using electronic transmission microscopy, Lucas et al. (2012a) observed that clove, lemongrass, citronella, and melaleuca essential oils at $0.1 \%$ caused damages to the cell structure of $X$. vesicatoria, however, they were not capable of inhibiting bacterial growth, thus indicating that some cells remained viable and promoted bacterial multiplication. Additionally, other factors might influence bioactivity of essential oils, among which is the pathogen to be controlled and chemical composition of EOs. This chemical composition might be determined by cultivation conditions, climate, extraction method, harvest time, and organ harvested (BURT, 2004; FALEIRO et al., 2003),
QUEIROZ, M. F. et al.

and a different chemical composition might take on different bioactive properties (TORRAS et al., 2007). Guerra et al. (2014) and Silva et al. (2012a) did not observe a direct effect of sweet orange (Citrus sinensis L.) oil at a $0.5 \%$ concentration on Pcc. These results corroborate those obtained for sour orange oil at $0.75 \%$ in our study.

Kale treated with lemongrass oil, before or after inoculation, showed INC of $0 \%$, representing $100 \%$ of disease control, significantly differing from the other treatments when applied prior to inoculation. However, when applied after inoculation, it did not differ from clove oil, which provided a control percentage of $71.42 \%(P \leq 0.05)$ (Table 2).

Table 2. Effect of essential oils on reduced incidence of soft rot caused by Pectobacterium carotovorum subsp. brasiliensis on kale under greenhouse conditions.

\begin{tabular}{lllll}
\hline Treatments/ & $\mathrm{INC}^{*}$ & \multicolumn{2}{c}{$\%$ control $^{4}$} \\
\cline { 2 - 5 } Concentrations (\%) & Pre $^{2}$ & Post $^{3}$ & Pre & Post \\
\hline Lemongrass (0.5) & $0.00 \mathrm{a}^{1}$ & $0.00 \mathrm{a}$ & 100 & 100 \\
Clove (0.25) & $50 \mathrm{~b}$ & $25 \mathrm{ab}$ & 42.85 & 71.42 \\
Citronella (0.75) & $75 \mathrm{~b}$ & $62.5 \mathrm{bc}$ & 14.28 & 28.57 \\
Melaleuca (0.75) & $75 \mathrm{~b}$ & $62.5 \mathrm{bc}$ & 14.28 & 28.57 \\
Palmarosa (0.5) & $75 \mathrm{~b}$ & $50 \mathrm{bc}$ & 14.28 & 42.85 \\
Bergamot (1) & $62.5 \mathrm{~b}$ & $62.5 \mathrm{bc}$ & 28.57 & 28.57 \\
Orange (0.75) & $62.5 \mathrm{~b}$ & $87.5 \mathrm{c}$ & 28.57 & 0.00 \\
Ginger (1) & $62.5 \mathrm{~b}$ & $75 \mathrm{bc}$ & 28.57 & 14.28 \\
Rosemary (1) & $62.5 \mathrm{~b}$ & $50 \mathrm{bc}$ & 28.57 & 42.85 \\
Sage (1) & $75 \mathrm{~b}$ & $62.5 \mathrm{bc}$ & 14.28 & 28.57 \\
Control & $87.5 \mathrm{~b}$ & $87.5 \mathrm{c}$ & $\mathrm{NA}$ & $\mathrm{NA}$ \\
\hline CV(\%) & 22.76 & 23.75 & $\mathrm{NA}$ & $\mathrm{NA}$ \\
\hline
\end{tabular}

${ }^{1}$ Means followed by the same letter on the column do not differ from each other according to Duncan's test $(P \leq 0,05){ }^{2}$ Treatment application prior to inoculation. ${ }^{3}$ Treatment application after inoculation. *Data transformed by the equation $\sqrt{ }(\mathrm{x}+0.5)$ to better fit the assumptions of the analysis of variance (ANOVA). Incidence (INC), expressed by the percentage of diseased plants; ${ }^{4} \mathrm{Compared}$ to control treatment; Not applicable (NA).

Essential oils are known for their direct antimicrobial activity and resistance inducing activity on plants (AMINIFARD; MOHAMMADI, 2013; LUCAS et al., 2012a; LUCAS et al., 2012b; PEREIRA et al., 2008; PEREIRA et al., 2012). Lemongrass oil effectively reduced disease incidence in both application periods; this is probably related to its direct action and defenseeliciting activity. A similar result was found by Lucas et al. (2012a) who observed that lemongrass oil at $0.1 \%$ applied pre- and post-inoculation promoted a significant reduction in bacterial spot of tomato. Guerra et al. (2014), also evaluating the potential of different essential oils on reduced soft rot severity in chinese cabbage caused by Pcc, observed that lemongrass oil at $0.5 \%$ significantly reduced severity compared to the control treatment, attributing this result to a potential resistanceinducing activity.

Clove, citronella, melaleuca, palmarosa, bergamot, rosemary, and sage oils did not show the expected results compared to the effective bioactivity showed in vitro assays. However, in vitro tests not always are representative as pathogens behave differently when they are both interacting with plants and exposed to environmental variables. In general, inhibitory concentrations observed in vitro must be increased when applied in vivo in order to maintain the same effectiveness (BURT, 2004). However, clove oil promoted a higher percentage of disease control, $71.42 \%$, when applied after inoculation, thus emphasizing its more effective direct antibacterial activity. Positive results using clove oil in plant 
Essential oils...

disease control have already been observed. Huang and Lakshman (2010) observed that clove oil at $0.5 \%$ provided $100 \%$ control of tomato bacterial wilt. In addition, Amorim et al. (2011) observed $25 \%$ effectiveness in banana moko control using clove oil at $3.75 \%$.

The major chemical component of clove oil is eugenol (COSTA et al., 2011; SCHERER et al.,
QUEIROZ, M. F. et al.

2009), whereas the major component of lemongrass oil is citral (isometric mixture of neral and geranial) (GUIMARÃES et al., 2011). Analysis of the chemical composition of clove essential oil showed high contents of eugenol (91.9\%) (Table 3), and lemongrass oil showed high contents of neral $(34.1 \%)$ and geranial $(42,9 \%)$ (Table 4$)$.

Table 3. Chemical composition of essential oil from clove

\begin{tabular}{llll}
\hline Constituent & $\mathbf{A I}_{\text {lit }}{ }^{1}$ & $\mathbf{A I}_{\text {calc }}{ }^{2}$ & $\mathbf{\%} \pm \mathbf{S D}^{\mathbf{3}}$ \\
\hline Eugenol & 1356 & 1360 & $91,9 \pm 0,2$ \\
$\beta$-caryophyllene & 1417 & 1419 & $6,4 \pm 0,2$ \\
$\alpha$-humulene & 1452 & 1455 & $1,3 \pm 0$ \\
$\delta$-cadinene & 1522 & 1526 & Trace \\
caryophyllene oxide & 1582 & 1587 & $0,4 \pm 0,1$ \\
\hline
\end{tabular}

${ }^{1} \mathrm{AI}_{\mathrm{lit}}=$ arithmetic index from literature; ${ }^{2} \mathrm{AI}_{\text {calc }}=$ calculated arithmetic index; ${ }^{3}$ Means \pm standard deviation from triplicate samples

Table 4. Chemical composition of essential oil from lemongrass

\begin{tabular}{llll}
\hline Constituent & $\mathbf{A I}_{\mathbf{L I T}} \mathbf{T}^{\mathbf{2}}$ & $\mathbf{A I}_{\mathbf{C A L C}} \mathbf{2}^{\mathbf{2}}$ & $\mathbf{\%} \pm \mathbf{S D}^{\mathbf{3}}$ \\
\hline$\alpha$-pinene & 932 & 935 & $0,1 \pm 0,1$ \\
Camphene & 946 & 947 & $0,7 \pm 0,1$ \\
6-methyl-5-hepten-2-one & 981 & 985 & $1,9 \pm 0,2$ \\
Limonene & 1029 & 1032 & $0,2 \pm 0,1$ \\
Z- $\beta$-ocimene & 1032 & 1037 & $0,2 \pm 0,0$ \\
E- $\beta$-ocimene & 1044 & 1048 & $0,1 \pm 0,0$ \\
4-nonanone & - & 1076 & $0,6 \pm 0,1$ \\
Linalool & 1095 & 1100 & $1,5 \pm 0,1$ \\
Citronellal & 1148 & 1150 & $0,4 \pm 0,0$ \\
Borneol & 1169 & 1171 & $0,2 \pm 0,0$ \\
Isocitral & 1177 & 1180 & $0,9 \pm 0,1$ \\
$\alpha$-terpineol & 1186 & 1190 & $0,6 \pm 0,1$ \\
Decanal & 1201 & 1202 & $0,1 \pm 0,0$ \\
Nerol & 1227 & 1230 & $0,3 \pm 0,1$ \\
Neral & 1235 & 1237 & $34,1 \pm 0,2$ \\
Geraniol & 1249 & 1253 & $5,3 \pm 0,2$ \\
Geranial & 1264 & 1268 & $42,9 \pm 0,4$ \\
Cyclosativene & 1369 & 1373 & $0,2 \pm 0,0$ \\
geranyl acetate & 1379 & 1383 & $4,1 \pm 0,1$ \\
$\beta$-cubebene/ $\beta$-elemene & 4 & 1391 & $0,1 \pm 0,1$ \\
$\beta$-caryophyllene & $1387 / 1389$ & 1422 & $2,2 \pm 0,0$ \\
$\alpha$-humulene & 1417 & 1459 & $0,4 \pm 0,1$ \\
germacrene D & 1452 & 1487 & $0,2 \pm 0,0$ \\
$\delta$-amorphene & 1484 & 1518 & $1,0 \pm 0,1$ \\
$\gamma$-cadinene & 1511 & 1514 & $0,7 \pm 0,1$ \\
caryophyllene oxide & 1513 & 1589 & $0,3 \pm 0,1$ \\
\hline A & 1582 & &
\end{tabular}

${ }^{1} \mathrm{AI}_{\mathrm{lit}}=$ arithmetic index from literature; ${ }^{2} \mathrm{AI}_{\text {calc }}=$ calculated arithmetic index; ${ }^{3}$ Means \pm standard deviation from triplicate samples; ${ }^{4}$ coeluted compounds

In vitro assays with lemongrass and clove essential oils and their major components showed differences as to their minimum Pcb growthinhibiting concentration (Table 5). Lemongrass essential oil completely inhibited the growth of Pcb at $0.5,0.25,0.125,0.0625 \%$, whereas its chemical component citral promoted total inhibition at all concentrations tested. On the other hand, clove oil 
promoted complete inhibition only at higher concentrations $(0.25$ and $0.125 \%)$ and its major chemical component, eugenol, did not effectively inhibit the growth of Pcb at any of the tested concentrations.

Table 5. Minimum inhibiting concentrations (MIC) of lemongrass and clove essential oils and their major chemical components against Pectoctobacterium carotovorum subsp. brasiliensis.

\begin{tabular}{llcll}
\hline Concentrations (\%) & Clove oil & Eugenol & $\begin{array}{l}\text { Lemongrass } \\
\text { oil }\end{array}$ & Citral \\
\hline 0.5 & $\mathrm{NA}$ & $\mathrm{NA}^{1}$ & $-{ }^{2}$ & - \\
0.25 & - & $+^{3}$ & - & - \\
0.125 & - & + & - & - \\
0.0625 & + & + & - & - \\
0.03125 & + & + & + & - \\
0.015625 & + & + & $\mathrm{NA}$ & $\mathrm{NA}$ \\
Growth control & + & + & + & + \\
Medium control & - & - & - & - \\
\hline
\end{tabular}

${ }^{1}$ (NA) Not applicable, ${ }^{2}(-)$ Absence of growth, ${ }^{3}(+)$ Microbial growth

Similar results were obtained by Lee et al. (2012) where the eugenol was found as main component of clove oil, but the diameter of inhibition zone at major concentration $(10 \mathrm{ul} / \mathrm{disc})$ was lower than in the treatment with clove oil.

In the current study, lemongrass oil at $0.125 \%$ applied post-inoculation and the chemical compound citral at $0.125 \%$ applied prior or after inoculation provided the highest percentages of disease control $(33.33,50$, and $100 \%$, respectively). Plants treated with citral at $0.125 \%$ after inoculation showed an INC of $0 \%$, significantly differing from the other treatments $(P \leq 0,05)$, except for the treatment with citral $0.125 \%$ prior to inoculation, which showed INC of $37.5 \%$. INC in treatments with clove oil at $0.125 \%$ and eugenol at $0.25 \%$ did not differ from the control treatment $(P \leq 0.05)$. However, clove oil at $0.125 \%$ applied after inoculation showed better effectiveness than its major component, providing a percentage of disease control of $16.67 \%$ (Figure 1).
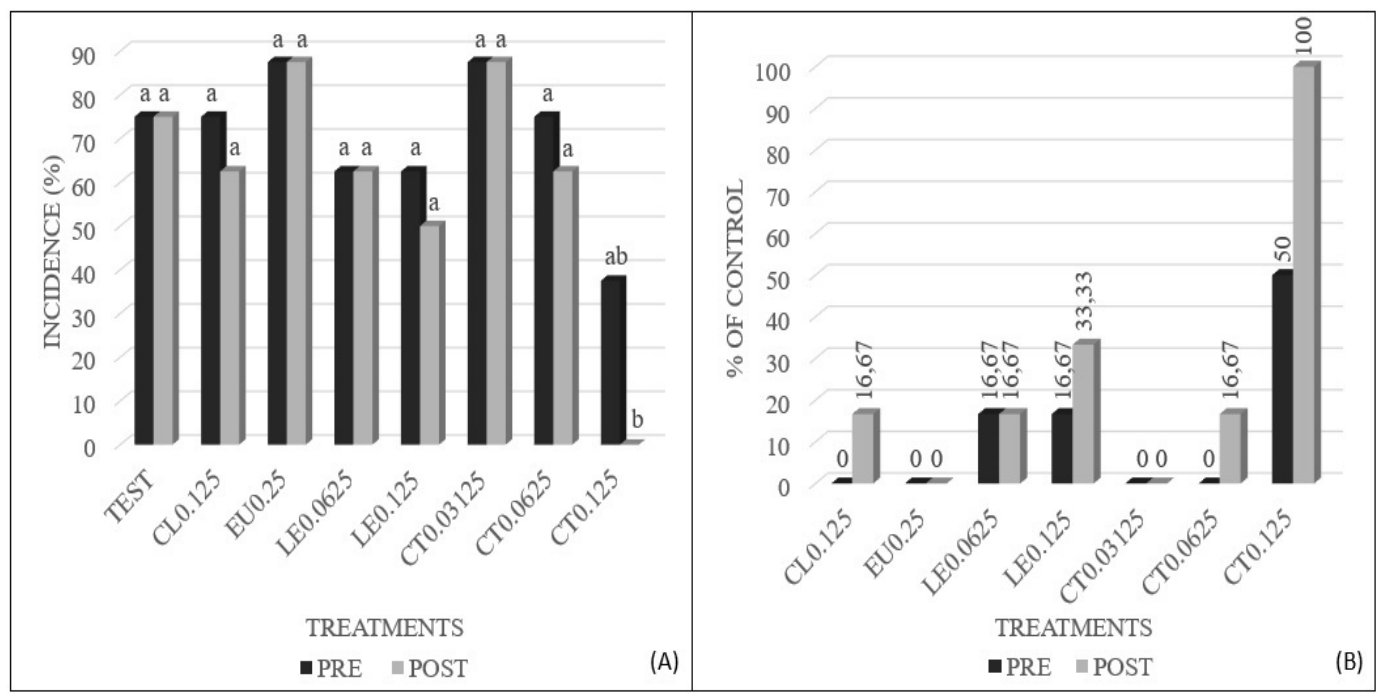

Figure 1. Effect of lemongrass and clove essential oils and their major components (citral and eugenol) on soft rot caused by Pectobacterium carotovorum subsp. brasiliensis, in kale.

Test (Control treatment); CL 0.125(clove oil at 0.125\%); EU 0.25 (eugenol at $0.25 \%$ ); LE 0.0625 (lemongrass at $0.0625 \%$ ); LE 0.125 (lemongrass at $0.125 \%$ ); CT 0.03125 (citral at $0.03125 \%$ ); CT 0.0625 (citral at $0.0625 \%$ ); CT 0.125 (citral at $0.125 \%$ ); Pre (treatment application prior to inoculation); Post (treatment application after inoculation). Means followed by the same letter do not differ according to Duncan's test $(P \leq 0.05)$.

The action mechanism of essential oils is usually associated to their major chemical components (BAKKALI et al., 2008), which show a wide activity spectrum, acting directly on pathogen structures (LUCAS et al., 2012a; NAZZARO et al., 
2013), as well as activating plant defense biochemical pathways (PEREIRA et al., 2008).

The antimicrobial activity of essential oils is not attributable to a unique mechanism but is related a several reactions involving the entire bacterial cell. More recently, Joshi et al. (2016) demonstrated that the phenolic volatiles carvacrol and eugenol act through the Quorum sensing machinery to inhibit specific virulence determinants in pectobacteria, such as biofilm formation and plant cell wall degrading enzymes (PCWDEs).

Considering the results obtained, we might infer that citral is the component responsible for the bactericide activity of lemongrass oil on Pcb and soft rot control on kale in the assays conducted. Differently, eugenol did not prove to be responsible for clove oil effectiveness as it showed unsatisfactory results even at a higher concentration than clove oil. This suggests that the action of clove oil is provided by the synergic effect of its
QUEIROZ, M. F. et al.

constituents. According to Burt (2004) and Bakkali et al. (2008), synergism is observed when the effect of combined substances is higher than their individual effects, once essential oils are complex mixtures of numerous molecules.

\section{CONCLUSION}

Lemongrass and clove essential oils proved to be a promising alternative to be employed as an integrated management method of soft rot of kale, thus reducing the use of agrochemicals, and consequently, contributing with reduced resistant microorganisms, risks to farmer's and consumers' health, and preserving the environment.

\section{ACKNOWLEDGMENTS}

The authors thank CAPES for their financial support for this work.

RESUMO: O objetivo do estudo foi avaliar o efeito de óleos essenciais no controle da podridão mole em couve. Os óleos essenciais de cravo a $0,25 \%$, capim-limão e palmarosa a $0,5 \%$, citronela, melaleuca e laranja a $0,75 \%$, bergamota, alecrim, sálvia e gengibre a $1 \%$ foram avaliados na inibição in vitro de Pectobacterium carotovorum subsp. brasiliensis $(\mathrm{Pcb})$ e controle da podridão mole em couve, pulverizados 72 horas antes ou sete horas após a inoculação. Os óleos essenciais de cravo, citronela, bergamota, alecrim, palmarosa, sálvia, melaleuca e capim-limão inibiram completamente o crescimento de Pcb. O óleo de capimlimão $(0,5 \%)$ promoveu $0 \%$ de incidência (INC) da doença (percentual de controle de $100 \%$ ), em ambos os períodos de inoculação. O óleo de cravo $(0,25 \%)$ proporcionou menor INC $(25 \%)$ quando aplicado após inoculação (percentual de controle de 71,42\%). Os óleos essenciais de capim-limão e cravo foram analisados por GC/FID (cromatografia gasosa/detector por ionização de chama) e por GC/MS (cromatografia gasosa/ espectometria de massas). Os componentes majoritários foram eugenol $(91,9 \%)$ no óleo de cravo e citral (neral$34,1 \%$ e geranial- 42,9\%) no óleo de capim-limão. A concentração inibitória mínima (CIM) dos óleos essenciais de capim-limão e cravo e de seus componentes majoritários (citral e eugenol, respectivamente) foi determinada por meio da técnica de macrodiluição em caldo, bem como foram avaliados, em diferentes concentrações, no controle da podridão mole em couve, pulverizados conforme descrito acima. A concentração inibitória mínima (CIM) foi de $0,03125 \%$ para o citral, e de 0,0625 e $0,125 \%$ para os óleos de capim-limão e cravo, respectivamente. O eugenol não apresentou CIM. O óleo de capim-limão a 0,125\% (pós-inoculação) e o citral $(0,125 \%)$, em ambos os períodos de inoculação, proporcionaram os maiores percentuais de controle $(33,33 ; 50$ e $100 \%$, respectivamente). O óleo de cravo a $0,125 \%$ (pós-inoculação) mostrou maior eficiência que o eugenol (0,25\%), promovendo um percentual de controle de $16,67 \%$. Os óleos essenciais de capim-limão e cravo destacaram-se na eficiência de controle da podridão mole em couve, sugerindo que esses óleos têm potencial para serem utilizados como agentes antibacterianos.

PALAVRAS-CHAVES: Brassica oleracea var. acephala. Controle alternativo. Capim-limão. Citral. Cravo. Eugenol. P. carotovorum subsp. brasiliensis.

\section{REFERENCES}

ADAMS, R. P. Identification of Essential Oil Components by Gas Chromatography/Mass Spectrometry. $5^{\text {th }}$ ed. Gruver: Texensis Publishing, 2017. 
AGROFIT. Sistema de Agrotóxicos Fitossanitários. Ministério da Agricultura, Pecuária e Abastecimento. Retrieved from http://agrofit.agricultura.gov.br/agrofit_cons/principal_agrofit_cons.Access in: 20 Out. 2018.

ALVES, A. O.; SANTOS, M. M. B.; SANTOS, T. C. G.; SOUZA, E. B.; MARIANO, R. L. R. Biofumigation with essential oils for managing bacterial wilt of sweet peppers. Journal of Plant Pathology, Pisa, v. 96, n. 2, p. 363-367, 2014. http://dx.doi.org/10.4454/JPP.V96I2.046

AMINIFARD, H. M.; MOHAMMADI, S. Essential oils to control Botrytis cinerea in vitro and in vivo on plum fruits. Journal of the Science of Food and Agriculture, London, v.93, n. 2, p. 348-353, 2013.

https://doi.org/10.1002/jsfa.5765

AMORIM, E. P. R.; ANDRADE, F. W. R.; MORAES, E. M. S.; SILVA, J. C.; LIMA, R. S.; LEMOS, E. E. P. Atividade antibacteriana de óleos essenciais e extratos vegetais sobre o desenvolvimento de Ralstonia solanacearum em mudas de bananeira. Revista Brasileira de Fruticultura, Jaboticabal, Volume especial, p. 392-398, 2011. https://doi.org/10.1590/S0100-29452011000500050

BAKKALI, F.; AVERBECK, S.; AVERBECK, D.; IDAOMAR, M. Biological effects of essential oils - A review. Food and Chemical Toxicology, Exeter, v. 46, n. 2, p. 446-475, 2008.

https://doi.org/10.1016/j.fct.2007.09.106

BENELLI, A. I. H.; DENARDIN, N. D.; FORCELINI, C. A. Ação do acibenzolar-S-metil aplicado em tubérculos e plantas de batata contra canela preta, incitada por Pectobacterium carotovorum subsp. atrosepticum atípica. Fitopatologia Brasileira, Brasília, v. 29, n.3, p. 263-267, 2004. https://doi.org/10.1590/S0100-41582004000300004

BURT, S. Essential oils: their antibacterial properties and potential applications in foods - a review.

International Journal of Food Microbiology, Amsterdam, v. 94, n. 3, p. 233-253, 2004.

https://doi.org/10.1016/j.ijfoodmicro.2004.03.022

CHARKOWSKI, A. O. Biology and control of Pectobacterium in potato. American Journal of Potato

Research, Orono, v.92, n. 2, p. 223-229, 2015. https://doi.org/10.1007/s 12230-015-9447-7

CLINICAL LABORATORY STANDARDS INSTITUTE. Methods for Dilution Antimicrobial Susceptibility Tests for Bacteria That Grow Aerobically. 10 ${ }^{\text {th }}$ ed. Wayne: CLSI, 2015.

COSTA, C. M. G. R.; SANTOS, M. S.; BARROS, H. M. M.; AGRA, P. F. M.; FARIAS, M. A. A. Óleo essencial de citronela no controle da bactéria fitopatogênica Erwinia carotovora. Tecnologia \& Ciência Agropecuária, João Pessoa, v.2, n. 2, p. 11-14, 2008a.

COSTA, C. M. G. R.; SANTOS, M. S.; BARROS, H. M. M.; AGRA, P. F. M.; FARIAS, M. A. A. Inibição do crescimento bacteriano in vitro de Erwinia carotovora pelo óleo essencial de alecrim. Tecnologia \& Ciência Agropecuária, João Pessoa, v. 2, n. 2, p. 7-10, 2008 b.

COSTA, A. R. T.; AMARAL, M. F. Z. J.; MARTINS, P. M.; PAULA, J. A. M.; FIUZA, T. S.; TRESVENZOL, L. M. F.; PAULA, J. R.; BARA, M. T. F. Ação do óleo essencial de Syzygium aromaticum (L.) Merr. \& L.M. Perry sobre as hifas de alguns fungos fitopatogênicos. Revista brasileira de plantas medicinais, Botucatu, v. 13, n. 2, p. 240-245, 2011. https://doi.org/10.1590/S1516-05722011000200018

DEBERDT, P.; DAVEZIES, I.; CORANSON-BEAUDU, R.; JESTIN, A. Efficacy of Leaf Oil from Pimenta racemosa var. racemosa in Controlling Bacterial Wilt of Tomato. Plant disease, Saint Paul, v. 102, n. 1, p. 124-131, 2018. https://doi.org/10.1094/PDIS-04-17-0593-RE

DUARTE, V.; BOER, S. H. D.; WARD, L. J.; OLIVEIRA, A. M. R. D. Characterization of atypical Erwinia carotovora strains causing blackleg of potato in Brazil. Journal of Applied Microbiology, Oxford, v.96, n. 3, p. 535-545, 2004. https://doi.org/10.1111/j.1365-2672.2004.02173.x 
FALEIRO, M. L.; MIGUEL, M. G.; LADEIRO, F.; VENÂNCIO, F.; TAVARES, R.; BRITO, J. C.; FIGUEIREDO, A. C.; BARROSO, J. G.; PEDRO, L. G. Antimicrobial activity of essential oils isolated from Portuguese endemic species of Thymus. Letters in Applied Microbiology, Oxford, v. 36, n.1, p. 35-40, 2003. https://doi.org/10.1046/j.1472-765X.2003.01259.x

FERNÁNDEZ, M. M. R.; LOPÉZ, M. C.; PÉREZ, Y. S.; BRITO, D.; OCA, R. M.; MARTINÉZ, Y.; PÉREZ, O. P. Actividad antibacteriana de aceites essenciales sobre Pectobacterium carotovorum subsp. carotovorum. Revista Protección Vegetal, La Habana, v. 29, n. 3,1 p. 97-203, 2014.

FILGUEIRA, F. A. R. Novo manual de olericultura: agrotecnologia moderna na produção e comercialização de hortaliças. $3^{\mathrm{a}}$ ed. Viçosa, MG: Universidade Federal de Viçosa, 2008.

GARDAN, L.; GOUY, C.; CHRISTEN, R.; SAMSON, R. Elevation of three subspecies of Pectobacterium carotovorum to species level: Pectobacterium atrosepticum sp. nov., Pectobacterium betavasculorum sp. nov., Pectobacterium wasabiae sp. nov. International Journal of Systematic and Evolutionary Microbiology, Reading, v. 53, n. 2, p. 381-391, 2003. https://doi.org/10.1099/ijs.0.02423-0

GUERRA, M. L.; GUERRA, Y. L.; SOUZA, E. B.; MARIANO, R. L.; HENRY, R. Essential plant oils in reducing the intensity of soft rot in Chinese cabbage. Revista Ciência Agronômica, Fortaleza, v. 45, n. 4, p. 760-766, 2014. https://doi.org/10.1590/S1806-66902014000400014

GUIMARÃES, L. G. L.; CARDOSO, G. M.; SOUSA, E. P.; ANDRADE, J.; VIEIRA, S. S. Atividades antioxidante e fungitóxica do óleo essencial de capim-limão e do citral. Revista Ciência Agronômica, Fortaleza, v. 42, n. 2, p. 464-472, 2011. https://doi.org/10.1590/S1806-66902011000200028

HADAS, R.; KRITZMAN, G.; GEFEN, T.; MANULIS, S. Detection, quantification and characterization of Erwinia carotovora spp. carotovora contaminating pepper seeds. Plant Pathology, Oxford, v. 50, n. 1, p. 117 123, 2001. https://doi.org/10.1046/j.1365-3059.2001.00540.x

HAUBEN, L.; MOORE, E. R.; VAUTERIN, L.; STEENACKERS, M.; MERGAERT, J.; VERDONCK, L.; SWINGS, J. Phylogenetic position of phytopathogens within the Enterobacteriaceae. Systematic and Applied Microbiology, Munich, v.21, n. 3, p. 384-397, 1998. https://doi.org/10.1016/S0723-2020(98)80048-9

HUANG, K.; LAKSHMAN, D. K. Effect of clove oil on plant pathogenic bacteria and bacterial wilt of tomato and geranium. Journal of Plant Patholology, Pisa, v. 92, n. 3, p. 701-707, 2010.

INOUE-NAGATA, A. K.; LOPES, C. A.; REIS, A.; PEREIRA, R. B.; QUEZADO-DUVAL, A. M.; PINHEIRO, J. B.; LIMA, M. F. Doenças do tomateiro. In: AMORIM, L.; REZENDE, J. A. M; BERGAMIN FILHO, A.; CAMARGO, L. E. A. (Ed.). Manual de fitopatologia. Doenças das plantas cultivadas. 5 th ed. São Paulo: Agronômica Ceres, 2016. v. 2, p. 697-731.

JEONG, M. R.; PARK, P. B.; KIM, D. H.; JANG, Y. S.; JEONG, H. S.; CHOI, S. H. Essential oil prepared from Cymbopogon citrates exerted an antimicrobial activity against plant pathogenic and medical microorganisms. Mycobiology, Seoul, v. 37, n. 1, p. 48-52, 2009.

https://doi.org/10.4489/MYCO.2009.37.1.048

JOSHI, J. R.; KHAZANOV, N.; SENDEROWITZ, H.; BURDMAN, S.; LIPSKY, A.; YEDIDIA, I. Plant phenolic volatiles inhibit quorum sensing in pectobacteria and reduce their virulence by potencial binding to ExpI and ExpR proteins. Scientific Reports, London, v. 6, n. 38216, p. 1-15, 2016.

https://doi.org/10.1038/srep38126

LEE, Y. H.; CHOI, C. W.; KIM, S. H.; YUN, J. G.; CHANG, S.W.; KIM, Y.S.; HONG, J. K. Chemical Pesticides and Plant Essential Oils for Disease Control of Tomato Bacterial Wilt. The Plant Pathology Journal, Suwon, v. 28, n. 2, p. 32-39, 2012. https://doi.org/10.5423/PPJ.OA.10.2011.0200 
LEE, D. H.; KIM, J.; LIM, J.; HAN, S.; HEU, S. Genetic diversity of Pectobacterium carotovorum subsp. brasiliensis isolated in Korea. The Plant Pathology Journal, Suwon, v. 30, n. 2, p. 117-124, 2014. https://doi.org/10.5423/PPJ.OA.12.2013.0117

LUCAS, G. C.; ALVES, E.; PEREIRA, R. B.; PERINA, F. B.; SOUZA, R. M. Antibacterial activity of essential oils on Xanthomonas vesicatoria and control of bacterial spot in tomato. Pesquisa Agropecuária Brasileira, Brasília, v.47, n. 3, p. 351-359, 2012a. https://doi.org/10.1590/S0100-204X2012000300006

LUCAS, G. C.; ALVES, E.; PEREIRA, R. B.; ZACARONI, A. B.; PERINA, F. J.; SOUZA, R. M. Indian clove essential oil in the control of tomato bacterial spot. Journal of Plant Pathology, Pisa, v. 94, n. 1, p. 45$51,2012 \mathrm{~b}$.

MANSFIELD, J.; GENIN, S.; MAGORI, S.; CITOVSKY, V.; SRIARIYANUM, M.; RONALD, P.; DOW, M.; VERDIER, V.; BEER, S. V.; MACHADO, M. A.; TOTH, I.; SALMOND, G.; FOSTER, G. D. Top 10 plant pathogenic bacteria in molecular plant pathology. Molecular Plant Pathology, Oxford, v. 13, n. 6, p. 614-629, 2012. https://doi.org/10.1111/j.1364-3703.2012.00804.x

MARIANO, R. L. R.; SILVEIRA, E. B.; ASSIS, S. M. P.; GOMES, A. M. A.; OLIVEIRA, I. S.; NASCIMENTO, A. R. P. Diagnose e manejo de fitobacterioses de importância no Nordeste brasileiro. In: MICHEREFF, S. J.; BARROS, R. (Ed). Proteção de plantas na agricultura sustentável. Recife: Imprensa Universitária, UFRPE, 2001. cap. 6, p. 141-170.

MARIANO, R. L. R.; SILVEIRA, E. B.; ALVARADO, I. DEL C. M.; SILVA, A. M. F. Bactérias fitopatogênicas pectonolíticas dos gêneros Pectobacterium e Dickeya. Anais da Academia Pernambucana de Ciência Agronômica, Recife, v. 2, p.121-153, 2005.

MARINGONI, A. C.; SILVA JR., T. A. F. Doenças das Brássicas. In: AMORIM, L.; REZENDE, J. A. M; BERGAMIN FILHO, A.; CAMARGO, L. E. A. Manual de fitopatologia. Doenças das plantas cultivadas. 5 th ed. São Paulo: Agronômica Ceres, 2016. v. 2, p. 165-173.

NABHAN, S.; SOLKE, H.; DE BOER, H. S.; MAISS, E.; WYDRA, K. Pectobacterium aroidearum sp. nov., a soft rot pathogen with preference for monocotyledonous plants. International Journal of Systematic Evolutionary Microbiology, Reading, v. 63, n. 7, p. 2520-2525, 2013. https://doi.org/10.1099/ijs.0.046011-0

NAZZARO, F.; FRATIANNI, F.; DE MARTINO, L.; COPPOLA, R.; DE FEO, V. Effect of essential oils on pathogenic bacteria. Pharmaceuticals, Basel, v. 6, n. 12, p. 1451-1474, 2013.

https://doi.org/10.3390/ph6121451

PARET, M. L.; CABOS, R.; KRATKY, B. A.; ALVAREZ, A. M. Effect of plant essential oils on Ralstonia solanacearum race 4 and bacterial wilt of edible ginger. Plant Disease, Saint Paul, v. 94, n. 5, p. 521-527, 2010. https://doi.org/10.1094/PDIS-94-5-0521

PEREIRA, R. B.; ALVES, E.; RIBEIRO JÚNIOR, P. M.; RESENDE, M. L. V.; LUCAS, G. C.; FERREIRA, J. B. Extrato de casca de café, óleo essencial de tomilho e acibenzolar-S-metil no manejo da cercosporiose-docafeeiro. Pesquisa Agropecuária Brasileira, Brasília, v. 10, n. 10, p. 1287-1296, 2008.

https://doi.org/10.1590/S0100-204X2008001000005

PEREIRA, R. B.; LUCAS, C. G.; PERINA, J. F.; RIBEIRO JÚNIOR, M. P.; ALVES, E. Óleo essencial de citronela no controle e na ativação de respostas de defesa do cafeeiro contra a ferrugem e cercosporiose. Activation of coffee plants defense response against rust and brown eye spot. Ciência agrotécnica, Lavras, v. 36, n. 4, p. 383-390, 2012. https://doi.org/10.1590/S1413-70542012000400001

QUEIROZ, M. F.; ALBUQUERQUE, G. M. R.; GAMA, M. A. S.; MARIANO, R. L. R.; MORAES, A. J. G.; SOUZA, E. B.; SOUZA, J. B.; DA PAZ.; C. D.; PEIXOTO, A. R. First report of soft rot in kale caused by 
Pectobacterium carotovorum subsp. brasiliensis in Brazil. Plant disease, Saint Paul, v. 101, n. 12, p. 2144, 2017. https://doi.org/10.1094/PDIS-02-17-0266-PDN

REN, J.; PETZOLDT, R.; DICKSON, M. H. Genetics and population improvement resistance to bacterial soft rot Chinese cabbage. Euphytica, Dordrecht, v. 117, n. 3, p.197-207, 2001.

SAMSON, R.; LEGENDRE, J. B.; CHRISTEN, R.; ACHOUAK, W.; GARDAN, L. Transfer of Pectobacterium chrysanthemi (Burkholder et al. 1953) Brenner et al. 1973 and Brenneria paradisiaca to the genus Dickeya gen. nov. as Dickeya chrysanthemi comb. nov. and Dickeya paradisiaca comb. nov. and delineation of four novel species, Dickeya dadantii sp. nov., Dickeya dianthicola sp. nov., Dickeya dieffenbachiae sp. nov. and Dickeya zeae sp. nov. International Journal of Systematic and Evolutionary Microbiology, Reading, v. 55, n. 4, p. 1415-1427, 2005. https://doi.org/10.1099/ijs.0.02791-0

SCHERER, R.; WAGNER, R.; DUARTE, M. C. T.; GODOY, H. T. Composição e atividades antioxidante e antimicrobiana dos óleos essenciais de cravo-da-índia, citronela e palmarosa. Revista Brasileira de Plantas Medicinais, Botucatu, v. 11, n. 4, p. 442- 449, 2009. https://doi.org/10.1590/S1516-05722009000400013

SILVA, M. T. N.; USHIMARU, P. I., BARBOSA, L.N.; CUNHA, M. L. R. S.; FERNANDES JÚNIOR, A. Atividade antibacteriana de óleos essenciais de plantas frente a linhagens de Staphylococcus aureus e Escherichia coli isoladas de casos clínicos humanos. Revista Brasileira de Plantas de Medicinais, Botucatu, v. 11, n. 3, p. 257-262, 2009. https://doi.org/10.1590/S1516-05722009000300005

SILVA, C. L.; SOUZA, E. B.; FELIX, K. C. S.; SANTOS, A. M. G.; SILVA, M. V.; MARIANO, R. L. R. Óleos essenciais e extratos vegetais no controle da podridão mole em alface crespa. Horticultura Brasileira, Brasília, v. 30, n. 4, p. 632-638, 2012a. https://doi.org/10.1590/S0102-05362012000400012

SILVA, C. P.; GARCIA, K. G. V.; SILVA, R. M.; OLIVEIRA, L. A. A; TOSTA, M. S. Desenvolvimento inicial de mudas de couve-folha em função do uso de extrato de alga (Ascophyllum nodosum). Revista Verde de Agroecologia e Desenvolvimento Sustentável, Pombal, v. 6, n. 1, p. 07, 2012 b.

SILVA, A. N.; UETANABARO, A. P.; LUCCHESE, A. M. Chemical Composition and Antibacterial Activity of Essential Oils from Myrcia alagoensis (Myrtaceae). Natural Product Communications, Westerville, v. 8, n. 2, p. 269-271, 2013. https://doi.org/10.1177/1934578X1300800235

SILVA, E. L.; MARTINS, S. J.; ALVES, E. Essential oils for the control of bacterial speck in tomato crop. African Journal of Agricultural Research, [s.l.], v. 9, n. 34, p. 2624-2629, $2014 \mathrm{a}$. https://doi.org/10.5897/AJAR2014.8918

SILVA, M. S.; CARVALHO, F. C. Q.; SILVA, J. R.; LINS, S. R. O.; OLIVEIRA, S. M. A. Uso de antagonistas e produtos alternativos no manejo pos-colheita da podridão mole em pimentão. Revista Ciência Agronômica, Fortaleza, v. 45, n. 4, p. 718-725, 2014b. https://doi.org/10.1590/S1806-66902014000400009

SILVA, E.O.; ALVES, E.; FERREIRA, T.C.; ALBUQUERQUE, C.A.C. Óleos essenciais no controle da pinta bacteriana e na ativação de respostas bioquímicas em tomateiro. Summa Phytopathologica, Botucatu, v.43, n.3, p.212-217, 2017. https://doi.org/10.1590/0100-5405/2167

SOTELO-BOYÁS, M. E.; VALVERDE-AGUILAR, G.; PLASCENCIA-JATOMEA, M.; CORREAPACHECO, Z. N.; JIMENÉZ-APARICIO, A.; SOLORZA-FERIA, J.; BARRERA-NECHA, L.; BAUTISTA BAÑOS, S. Characterization of chitosan nanoparticles added with essential oils. In vitro effect on Pectobacterium carotovorum. Revista Mexicana de Ingeniería Química, Ciudad de México, v. 14, n. 2, p. 589-599, 2015.

TORRAS, J.; GRAU, M. D.; LÓPEZ, J. F.; HERAS, F. X. Analysis of essential oils from chemotypes of Thymus vulgaris in Catalonia. Journal of Science of Food and Agriculture, London, v. 87, n. 12, p. 23272333, 2007. https://doi.org/10.1002/jsfa.2995 